Z Badań nad Książką i Księgozbiorami Historycznymi 2019. T. specjalny: Dla Niepodległej The Studies into the History of the Book and Book Collections 2019. Special issue: For an Independent Poland

\title{
Translations of books for children and young adults in Poland 1918-1939 (a research reconnaissance)
}

\begin{abstract}
Based on the bibliography method (mainly Bibliografia literatury dla dzieci i młodzieży 19181939. Literatura polska i przekłady, by B. Krassowska i A. Grefkowicz, Warszawa 1995), the article presents the extent of foreign literature for young people translated into Polish, edited in Poland in 1918-1939. The most popular languages, literary genres, bestseller authors and titles, the intensity of publishing in periods, the biggest publishers, and the most popular series are analyzed. Besides classics, many foreign light titles were published, because of the lack of such literature in the Polish book market. They were attacked by literary critics and educators, but very widely-read in fact. The abundance and variety of foreign literature for children and young adults in 1918-1939 are emphasized. Language mosaic and author-subject diversity of these books had never been repeated after World War II, mainly due to political reasons.
\end{abstract}

Key words: translations - literature for children and young adults - Poland - 1918-1939.

„Z Badań nad Książką i Księgozbiorami Historycznymi” - Udział zagranicznych recenzentów w ocenie publikacji; Stworzenie anglojęzycznej wersji wydawniczej publikacji; Digitalizacja tomów archiwalnych rocznika w celu zapewnienia otwartego dostępu do nich przez Internet oraz wdrożenie i utrzymanie cyfrowej platformy redakcyjnej - zadanie finansowane w ramach umowy $\mathrm{nr}$ 653/P-DUN/2019 ze środków Ministra Nauki i Szkolnictwa Wyższego przeznaczonych na działalność upowszechniającą naukę. 
History of literature for children and young adults in Poland in the interwar period is hardly explored or described. In addition to the synthesis by Józef Zbigniew Białek ${ }^{1}$, already requiring a supplement, as well as personal entries in dictionaries, (Słownik literatury dziecięcej i młodzieżowej ${ }^{2}$, Leksykon literatury dla dzieci i młodzieży $y^{3}$ ), there are only a few works (articles rather than monographs) describing selected topics, like journals ${ }^{4}$, publishing series ${ }^{5}$, specific types of books ${ }^{6}$, literary works ${ }^{7}$, problems of reading promotion ${ }^{8}$ and education through literature ${ }^{9}$, as well as reading surveys and their results ${ }^{10}$. Transfer of foreign literature into the Polish publishing market in that time has not been explored by the researchers earlier as well, although the problem of publishing reception of foreign authors was discussed in the works mentioned above (compendium of J. Z. Białek and dictionaries of literature for young readers $\left.{ }^{11}\right)$; there are also a few studies of reception of specific literature types or authors ${ }^{12}$.

1 J.Z. Białek, Literatura dla dzieci i młodzieży w latach 1918-1939, Warszawa 1987.

2 Stownik literatury dziecięcej i młodzieżowej, ed. by B. Tylicka, G. Leszczyński, Wrocław 2002.

3 S. Frycie, M. Ziółkowska-Sobecka, W. Bojda, Leksykon literatury dla dzieci i młodzieży, Piotrków Trybunalski 2007.

4 E.g. I. Socha, Czasopisma dla młodzieży - literatura piękna - wychowanie literackie (19181939), Katowice 1990; J. Plis, "Pod Znakiem Maryi". Miesięcznik Zwiazku Sodalicji Mariańskich Młodzieży Szkót Średnich w Polsce (1920-1939), [in:] O etosie ksiażki. Studia z dziejów bibliotek i kultury czytelniczej, ed. by T. Wilkoń, Katowice 2017, pp. 757- 770.

5 E.g. B. Staniów, Serie ksiązek popularnonaukowych dla dzieci i młodzieży w Polsce międzywojennej jako źródto informacji o świecie, nauce i człowieku (na wybranych przyktadach), [in:] Przestrzeń informacyjna ksiażki, ed. by J. Konieczna, S. Kurek-Kokocińska, H. Tadeusiewicz, cooperation R. Kępa, M. Przybysz-Stawska, Łódź 2009, pp. 339-353.

6 E.g. E. Repucho, Ksiażka dla dzieci w stużbie estetyki druku. Publikacje dwudziestolecia międzywojennego, "Bibliotheca Nostra" 2016, no 1 (43), pp. 51-65; Z. Budrewicz, Ekodyskurs wychowawczy w międzywojennej literaturze dla dzieci i młodzieży, [in:] O etosie ksiażki. Studia z dziejów bibliotek $i$ kultury czytelniczej, ed. by T. Wilkoń, Katowice 2017, pp. 661-678.

7 E.g. N. Paprocka, Rynkowe przygody Matego Księcia, czyli o przyczynach powstania dwunastu przekładów utworu Antoine'a de Saint-Exupéry'ego, "Filoteknos. Literatura dziecięca - Mediacja Kulturowa - Antropologia Dzieciństwa" 2010, no 1, pp. 146-158.

8 I. Michalska, Wychowanie do czytelnictwa uczniów szkót powszechnych w Drugiej Rzeczypospolitej, Łódź 2011.

9 B. Hadaczek, Wychowanie przez literaturę w Polsce międzywojennej (związi literatury dla dzieci z pedagogika), Warszawa-Poznań 1973.

10 J. Andrzejewska, Badania czytelnictwa w Polsce do 1939 r., "Studia o Książce" 1986, vol. 16, pp. 73-139; B. Staniów, Czytelnictwo książki popularnonaukowej dla dzieci i młodzieży w Polsce do 1989 roku (w świetle badań), "Bibliotheca Nostra. Śląski Kwartalnik Naukowy” 2016, no 1, pp. 105-126.

11 Mostly due to biographic entries in dictionaries.

12 E.g. T. Kieniewicz, Recepcja literatury amerykańskiej $w$ Polsce $w$ dwudziestoleciu międzywojennym, Warszawa 1977; A. Nikliborc, Od baśni do prawdy. Szkice dziejów literatury zachodniej dla dzieci i młodzieży, Warszawa 1981; M. Woźniak, K. Biernacka-Licznar, B. Staniów, Przekłady w systemie matych literatur: o włosko-polskich i polsko-włoskich tlumaczeniach dla dzieci i mtodzieży, ed. by M. Woźniak, Toruń 2014; N. Paprocka, Sto lat przekładów dla dzieci i młodzieży w Polsce. Francuska literatura dla młodych czytelników, jej polscy wydawcy i ich strategie (1918-2014), Kra- 
Although the interwar period can be considered exceptionally rich in publications for young readers, it was not homogenous - after regaining independence patriotism and schools' obligation of disseminating the highest cultural values was natural. Publishing production after 1933 slightly weakened due to the progressing crisis in the country. It is estimated that in the years 19281934 the book for the young reader accounted for almost a quarter of the total book publishing of belles lettres in Poland ${ }^{13}$. Multitude of publishing houses active in the book market of the $2^{\text {nd }}$ Republic of Poland, as well as increasing demand for publications for the young reader, enhanced interest in foreign authors and works, in particular of adventure and travel literature, fairy tales, legends, and fantasy ${ }^{14}$. Significant was also the character of the Polish authors' works, published in that time, and a certain hunger for books of the genres mentioned above. The following clear trends of Polish book for children and young adults production can be determined in the interwar period:

- the works based on or inspired by (or stylized) domestic folklore, presenting different kinds of folk creativity and its sense, like those by Zofia Rogoszówna, Janina Porazińska, Hanna Januszewska, Lucyna Krzemieniecka, Ewa Szelburg-Zarembina,

- unique poetry of Jan Brzechwa and Julian Tuwim, close to children imagination and way of thinking"15, characterized by "juggling of words, infantilism of sounds and connotations, word-formative and verbal searching, language humor, euphony and artistry" 16 ,

ków 2018. To some degree I analysed pre-war translations of American literature in the book Ksiażka amerykańska dla dzieci i młodzieży w Polsce w latach 1944-1989. Produkcja i recepcja, Wrocław 1996; S. Brzozowska, Andersen w Polsce. Historia recepcji wydawniczej, Wrocław 1970; B. Staniów, Grimm's Fairy Tales in Poland: the analysis of publishing production in the years 1895-2011, "Annales Universitatis Paedagogicae Cracoviensis. Studia ad Bibliothecarum Scientiam Pertinentia" 2014, [no] 12, pp. 5-18.

13 According to Stownik literatury polskiej XX wieku "one of the most significant structural changes in literary book production [compared to the previous century - BS] was increase of share of publications for young readers. They made $14,8 \%$ of titles and $9,7 \%$ of copies of all belles-lettres books (15,5\% and $15,8 \%$ of Polish literature) in the years $1877-1880$, in the years 1928-1934$24,6 \%$ and $26,8 \%$ respectively, in the years $1934-38$ - approximately $23 \%$ and $15 \%$, but in the years $1944-1986-26,2 \%$ and $46,9 \%$ (from $21,3 \%$ and $41,7 \%$ in the years $1976-1980$ up to $30,8 \%$ and $54,9 \%$ in 1986). Distance between amount of average edition of literature for children and young adults and for other readers increased significantly. In the years 1877-1880 it was hardly noticeable for Polish-language books (2228 copies and 2169 copies respectively), in the years 1928-1934 an average edition of the first group of publications was slightly higher than of the other one (3422 and 3036), in the years 1934-1938 by $60 \%$ lower, and in the whole post-war period again higher, as many as 2,5 times (58,6 thousand and 23,6 thousand)". Cited after: Stownik literatury polskiej XX wieku, ed. by A. Brudzka et al., Wrocław 1992, p. 980.

14 Actually, many fairy tales had also a subtitle "fantastical". There were also many mixed genres, e.g. fantasy- adventure novels.

15 J.Z. Białek, op. cit., p. 85.

16 Ibidem, p. 86. 
- folk tales, stories, literary legends, referring to tradition and history of Poland and its regions (Bronisława Ostrowska, Maria Kownacka, Janusz Korczak, Zofia Kossak-Szczucka, Halina Górska, Kornel Makuszyński),

- novels and psychological novels, e.g. by Helena Bobińska, Maria Dąbrowska, J. Korczak, Fryderyka Lazarusówna, Ewa Ostrowska, Kazimierz Rosinkiewicz, Zofia Żurakowska,

- socially-engaged prose, represented e.g. by Helena Boguszewska, Wanda Wasilewska, Gustaw Morcinek, K. Makuszyński,

- novels for girls (Maria Dunin-Kozicka, Halina Auderska, Maria Buyno-Arctowa, Jadwiga Korczakowska, Maria Kann),

- historical novels, written by both the classics (Józef Ignacy Kraszewski, Henryk Sienkiewicz, Walery Przyborowski, Zofia Bukowiecka, Zuzanna Morawska, Antonina Domańska, Wiktor Gomulicki) or other authors of that time (Aniela Gruszecka, Edmund Jezierski1 ${ }^{17}$, M. Dąbrowska, Maria Czeska-Mączyńska, Waleria Szalay-Groele, Kazimierz Konarski, Mieczysław Smolarski, Jan Parandowski), and its patriotic variant (B. Ostrowska and others) $)^{18}$,

- adventure and travel novel, represented (among others) by Aleksander Ludwik Janowski, Ferdynand Antoni Ossendowski, Janusz Makarczyk, Arkady Fiedler. There were also many sub-genres in this type, including a fantastic (Kazimierz Andrzej Czyżowski) or maritime one (Janusz Meissner, Maria Wardasówna, Zofia Dromlewiczowa),

- nature novel (Bohdan Dyakowski, Jan Sokołowski, Anna Lewicka, K. Rosinkiewicz, Jan Grabowski and many others).

It is worth noting that a few of the aforementioned authors were also translators of foreign works, for either adults or young readers. For instance, Rogoszówna translated The Rose and the Ring (Pierścień i róża) by William M. Thackeray and Abeille (Zazulki) by Anatol France, Januszewska Münchausen by Gottfried August A. Bürger and The Sorcerer's Apprentice (Uczeń czarnoksiężnika) by Johann Wolfgang Goethe, and Kann - works of Karol Čapek, František Hrubin and others.

Despite this diversity and slow turns towards literature free of any utilitarian programs, the history influence was too strong and - as states Ryszard Waksmund - all the same in that time still "literature for children and young adults had to consider temporary patriotic, education and propaganda goals

\footnotetext{
17 Correctly: Edmund Krüger.

18 This trend is presented by Anna Maria Krajewska in the book Trzy legendy. Walka o niepodległość i granice w polskiej międzywojennej literaturze młodzieżowej (Warszawa 2009), describing publications for children and young adults concerning Józef Piłsudski, the Polish Legions, the defence of Lwów in 1918, and the Bolshevik war. Titles concerning these topics were prohibited in the People's Republic of Poland.
} 
in the interest of the reborn homeland" ${ }^{19}$. Pupils' reading after school was given particular care. The Ministry of Religious Affairs and Public Education established in 1930 the literary prize for good book for young adults, and Sławomir Czerwiński underlined that exactly that kind of book shaped pupils' attitudes ${ }^{20}$ and aroused vivid feelings, "taught the sacred seriousness of life", had a decisive influence on world view and future decisions of the young generation $^{21}$. On the other hand, the need for adventure, travel, and novel for girls was very large, therefore the publishers, in the face of scarcity of domestic books of that kind, assimilated similar titles from Western works of literature; they found very fertile ground.

\section{The aim and range of the study, research methods, and sources}

The aim of this article is to present the size of editions of foreign literature for young readers in translations at the Polish publishing market in the years 1918-1939. The source for the study was Bibliografia literatury dla dzieci i młodzieży 1918-1939: literatura polska i przektady (Bibliography of literature for children and young adults 1918-1939: Polish literature and translations) the list developed by Bogumiła Krassowska and Alina Grefkowicz (Warszawa 1995). I applied the same qualification rules as these authors, i.e. I considered all editions they registered, recognizing that they passed the verification of a addressed reader - adapted to age and perception of a young reader. I also reated the authorship issues as they did, which was particularly important in regard of adaptations, studies and other changes popular in that time, imitating and in fact often changing the original text for the need of a Polish young recipient (they were also called "free translations" 22 in subtitles). I also took over

19 R. Waksmund, Od literatury dla dzieci do literatury dziecięcej (tematy, gatunki, konteksty), Wrocław 2000, p. 392.

20 It was strongly emphasised that books from children and young adults should influence citizen and patriotic feelings, promote sightseeing and regionalism, advantages of domestic landscapes and nature.

21 B. Hadaczek, op. cit., p. 38 .

22 Things are different with the versions described as "adapted Polish" ones. Some of these represented major changes of the original. In such cases the main author (either on the title page or in the bibliographic description in the list by Krassowska and Grefkowicz) was the Polish one, and the "Polish adaptation according to...(name of the original author" was mentioned in a subtitle. Fairy tales by Alexander Pushkin, Hans Christian Andersen or Charles Perrault were published many times in such versions, adapted by Halina Bokserówna. However, "authorised translations" were also published in that time, of either classic titles (e.g. Heart by Edmondo de Amicis, published by Gebethner \& Wolff, novels by Rudyard Kipling published by Wydawnictwo Polskie), or contemporary authors, e.g. fairy tales concerning nature for children by the German writer Waldemar Bonsels (1881-1952): Mario und die Tiere (The Adventures of Mario) (1928, Polish edition Marek w lesie 1930), authorised translation of Helena Sroczyńska, or Die Biene Maja und ihre Abenteuer [The Adventures of Maya the Bee] (1912, Polish edition Pszczótka Maja i jej przygody 1922 [1921], 
all data from bibliographic descriptions - either those placed on title pages (or other parts of books) or those settled by the authors, from other sources or autopsy. I described the editions mostly in regard to the works of literature (and languages) mostly translated, the most popular genres and popular publishing series, to which those books belonged. For understandable reasons, a complete set of descriptions was not taken into account on individual issues, because of frequent lack of relevant data in bibliographic descriptions (e.g. language of the translated original, publishing data: year, place of publication or publisher's name ${ }^{23}$ ). Texts of foreign authors, approaching Polish readers that time in original, as well as translations placed in school textbooks and magazines for children and young adults, are not discussed here, as well as scenic or film adaptations of any kind; these are separate and very wide topics.

\section{Translations of books for children and young adults in Poland in the years 1918-1939 in Polish publishing houses}

\subsection{Publishers, languages, and genres}

Works of foreign authors have always been approaching Polish readers in original versions, in noble houses, they were used e.g. by the governesses for teaching foreign languages. The most important masterpieces of world literature for children and young adults were translated before World War I; they have been read for many consecutive years, also in the same translations. The interwar period was characterized by a real "crop" of publishing companies, many of them dealt with editions for children and young adults, and almost 200 published foreign titles translated for young readers ${ }^{24}$. The largest publishers, i.e. those which published more than 100 titles, included: M. Arct (Warszawa), Księgarnia J. Przeworskiego (J. Przeworski Bookstore, Warszawa), Nowe Wydawnictwo Ch. I. Rosenweina (Ch. I. Rosenwein New Publishing House, Warszawa), Gebethner \& Wolff (Kraków-Warszawa), Księgarnia Popularna (The Popular Bookstore, Warszawa), Księgarnia Nakładowa (The Publishing Bookstore, Warszawa) ${ }^{25}$. More than 1800 books with works

1923, [1927] - two editions). The edition of 1923 by Dom Książki Polskiej informed: "z upoważnienia autora spolszczyła S.L." [“Authorised Polish translation by S.L.”] (alias unsolved). Adventures of a vivacious bee, curious about the nature, were translated into many languages and formed a basis for the scenario of the well-known cartoon series.

23 These deficiencies were noted in $20-30 \%$ of descriptions.

24 N. Kraśko, Instytucje wydawnicze w II Rzeczypospolitej, Warszawa 2001.

25 Interestingly, more than half of the companies publishing foreign literature for children and young adults edited no more than 2 titles, therefore it was a marginal activity for many of them. 
of foreign authors were published in total at that time. This is obviously an estimation only, based on bibliographic calculations. It is not equivalent to the number of published works, as they were often published several in one book ${ }^{26}$. Analysis of the bibliographic list of B. Krassowska and A. Grefkowicz reveals that the dynamics of publishing translation had been changing in the whole interwar period. An increasing trend can be observed in the mid-1920s (approx. 130 editions in 1928, which is the largest amount in this period), they were sinusoidal in the following years.

Re-publications were dominated by second (approx. one-third) and third (one-sixth) editions. However, there also were works published in a higher number of editions. The following editions were always numbered and properly signed. Publishers changed their profile and sometimes name, therefore this phenomenon is difficult to describe precisely, although it is a very important aspect of the popularity of individual titles. The example is Heart (It. Cuore, Pol. Serce) by Edmondo de Amicis, the novel for children published by the Gebethner \& Wolff 13 times after 1918, but including also editions with changed graphic design. The following editions of Hans Christian Andersen's tales, Robinson Crusoe (Przypadki Robinsona Kruzoe) by Daniel Defoe, Uncle Tom's cabin (Chata wuja Toma) by Harriet Elizabeth Beecher-Stowe, published by Gebethner \& Wolff in the inter period, were numbered consecutively, starting before World War I. Other publishers, e.g. M. Arct or Księgarnia Popularna, did the same.

English dominated among the languages from which translations were done. Every second title came from English-language literature (mostly British and American, but also Canadian), every fourth from German, and every tenth from French. The other approx. 15\% came from works of literature in: Czech, Italian, Russian, Spanish, and Swedish. Individual works represented Hebrew, Norwegian, Yiddish, Danish, Estonian, Icelandic, Dutch or Hungarian languages ${ }^{27}$.

Polish readers were most often acquainted with foreign travel and adventure works, represented by almost half of translations. Approximately one-third of the translation market belonged to fairy tales and legends of foreign authors, every tenth book could have been classified as fantasy; fiction, religious, nature and historical novels are even less represented ${ }^{28}$. At first $t$ these were works

26 According to J.Z. Białek, translations of foreign literature made approximately $20 \%$ of books for children and young adults production in the years 1918-1939 (J.Z. Białek, op. cit., p. 48). Quantitative analysis of translations is based on the bibliography of B. Krassowska and A. Grefkowicz confirms this thesis.

27 These are also estimated data, as these proportions refer to approximately $63 \%$ of translations registered in the bibliography - those for which language is noted in a bibliographic entry, or author origin and language of the original were identified.

28 Similarly, the topics of translations were settled for only approx. $88 \%$ of titles. 
of older authors, only in the 1930s. newer and current texts were more eagerly published. However, the time at which contemporary foreign titles reached Polish reader was varied in that period, usually quite long - ranging from a few to a dozen of years on average. For example, The Story of Ferdinand of Munro Leaf (1936, Polish edition Byczek Fernando 1939) or The Adventures of Sajo and Her Beaver People of Grey Owl was translated into Polish tree years after publishing the original (1935, Polish edition Sejdżio i jej bobry 1938), similarly the works of Erich Kästner, e.g. Emil und die Detektive (1928, Polish edition Emil i detektywi 1933, Eng. Emil and the Detectives), Pünktchen und Anton (1930, Polish edition Kruszynka i Antoś 1933, Eng. Anna Louise and Anton), Der 35. Mai oder Konrad reitet in die Südsee (1932, Polish edition 35 maja albo jak Konrad pojechat konno do mórz potudniowych 1936, Eng. The 35 th of May, or Conrad's Ride to the South Seas), Das fliegende Klassenzimmer (1933, Polish edition Latajaca klasa 1936, Eng. The Flying Classroom). Walentin Katajew's Samotny biaty żagiel (Eng. A White Sail Gleams) was published in Polish just two years after the original (1936, Polish edition 1938).

Publishers made Polish child to wait a long time for the classic also the titles from the $19^{\text {th }}$ century of Louisa May Alcott, known from Little Women (1868, first Polish edition Małe kobietki 1876), were published just at the end of the $20 \mathrm{~s}$. and in the $30 \mathrm{~s}$. of the $20^{\text {th }}$ century: Rosalynn (the sequel of Eight Cousins or The Aunt-Hill published in 1897) of 1875 was published in Polish for the first time in 1932 (Różyczka), Under the Lilacs - 41 years after the original (1878, first Polish edition W cieniu bzów 1929), Jack and Jill: A Village Story - 52 years after the American edition (1880, Polish edition Janek $i$ Julka 1932). Not until the interwar period (1937) the translation of Tanglewood Tales (Opowieści z zaczarowanego lasu) was published, A Wonder-Book for Girls and Boys (Mity greckie) of Nathaniel Hawthorne from the mid- $19^{\text {th }}$ century, and the novel Heidi by Johanna Spyri (originally published in 1880-81, Polish edition 1927), as well as The Heroes, Greek Fairy Tales by Charles Kingsley (1856, Polish edition Heroje, czyli klechdy greckie o bohaterach 1926). In the 30s. of the $20^{\text {th }}$ century the Polish readers learned the story about Polyanna (Polyanna, 1913, Polish edition 1936, Polyanna Grows Up 1915, Polish edition Polyanna dorasta 1936). It also seems that the popularity of some works among Polish readers was not followed by - seemingly logical - potential interest in other works of a given author. Edition of the sequel of renowned Alice's Adventures in Wonderland (Alicja w Krainie Czarów) was delayed up to 65 years. The novel by Lewis Carroll Through the Looking-Glass (O tym co Alicja odkryła po drugiej stronie lustra), originally published in 1871 , was premiered in Poland for the first time just in 1926 (with the title $W$ zwierciadlanym domu). Even the success of Anne of Green Gables by Lucy M. Montgomery (1908, first Polish edition 
Ania z Zielonego Wzgórza 1912) did not receive quick interest of the publishers in the following volumes of the cycle; they were published in interwar Poland from 12 to 16 years after the original ${ }^{29}$. Charles Perrault's fairy tales were published after World War II in Hanna Januszewska adaptation (Bajki babci Gaski 1697 1961, Bajki 1971), and the fairy tales of Marie Catherine d'Aulnoy, famous all over Europe, was published in Polish just in 1987. The Polish reader got a chance to know the funny adventures of Peter Rabbit Beatrix Potter, written at the beginning of the $20^{\text {th }}$ century, just in the $90 \mathrm{~s}$.! Many works of contemporary authors have not been translated at all, therefore Polish readers did not know the output of K. Čapek, Eleanor Farjeon, Piotr P. Jerszow, Iwan A. Kryłow and others before the war. Obviously, it is very difficult to determine the reasons of such publishers' decisions, although an economic account, mostly in case of smaller companies, was a priority, and decisions concerning publishing contemporary literature, in particular, the foreign one, have always been and are subject to a considerable risk.

2.2. Foreign bestsellers in the interwar period - the most popular authors, works, and their translators

The list of the most popular author, i.e. those whose works were published the most often, includes first of all Wilhelm and Jacob Grimm. Their fairy tales in different adaptations and alterations had as many as 154 editions in the years 1918$1939^{30}$, as much as the next two authors in this ranking, i.e. Jules Verne (79 editions) and H.C. Andersen (75 editions). Equivalent place was occupied by the Russian author of novels for girls Lidia Aleksiejewna Czarska ${ }^{31}$ (73 editions). The next was the extremely popular German novelist, known from his novels on the American Wild West, Karol May (68 editions). Thomas Mayne Reid (45), James Fenimore Cooper (41), Rudyard Kipling (35), G. Owl ${ }^{32}$ (35), D. Defoe $(35)^{33}$, James Oliver Curwood (28), Mark Twain (20), Louis Henry Boussenard (19), Robert Montgomery Bird (11), the authors of adventure novels, are on the following places. The authors of other genres were placed high in this ranking: a nature novel (Ernest T. Seton - 31), a novel for girls (L.M. Montgomery - 24, Frances E.H. Burnett - 17, L.M. Alcott-11), novels for boys (E. de Amicis - 23). More than 10 editions belong also to H.E. Beecher Stowe (23), Jonathan Swift

\footnotetext{
29 Selected volumes just after the World War II, in the 70s and 80s or at the beginning of the 90 s. of the $20^{\text {th }}$ century.

30 Both collections of tales and the tales published individually in small books were perceived as editions.

31 Also as Ludwika Czarska.

32 Also as Szara Sowa (Grey Owl), correct name: George Stensfeld Belaney.

33 Together with anonymous editions.
} 
(20), Ezop (16), Miguel de Cervantes Saavedra (14), Selma Lagerlöf(12), Elizabeth T. Smith (12), and Charles Dickens (10). A large group consists of the most read that time, bestseller novels for girls by Jean Webster (in particular DaddyLong-Legs, 1912, first Polish edition Dlugonoki Iks, 1926, hereafter Tajemniczy opiekun), and many other, less known sentimental novels for girls and fiction, family novels (e.g. by Robert Leighton, Hector Malot, Edna Lyall, Joan Gould). Prose writings of the Czech author Alfons B. Štastny was known to younger children (11 books), and J. Przeworski company published tales of Walt Disney (9 titles). The most productive translators of literature for children and young adults into Polish were the writers and poets: Elwira Korotyńska ${ }^{34}$, Janina Colonna-Walewska, Cecylia Niewiadomska ${ }^{35}$.

The unquestionable bestsellers of the interwar period - besides numerous editions of Grimm's fairy tales published in collections and individually - include also D. Defoe's story about Robinson Crusoe (34 editions under different titles), H.B. Stowe novel Uncle Tom's cabin (with different subtitles, 23 editions), and Gulliver's Travels of J. Swift (different title versions, 20 editions). Therefore, the most popular works were published in a specific "book-system": with the whole chain of versions copied, adapted, transformed, modified, shortened, what was mentioned in subtitles only with magic words "according to...", "adapted by..." or not mentioned at all. As many as 17 titles from the cycle of novels about Anne of Green Gables by L.M. Montgomery were published at that time, Heart by E. de Amicis and the story of Don Kichot by M. Cervantes Saavedra were published 14 times. Popularity of One Thousand and One Nights tales, adapted for children by different authors (24 editions) is worth mentioning, among many publications of fairy tales.

Translations of authors recognized as classics in world literature are also worth noting. These include, in addition to the aforementioned: Robert Louis Stevenson, Ferenc Molnar, J.M. Barry ${ }^{36}$, Ågot Gjems-Selmer, R. Kipling, Edith Nesbit, Hugh Lofting, Eleanor H. Porter ${ }^{37}$, Frances Courtenay-Baylor, Angela Brazil, Brenda Page, Alan Milne, Pamela Lyndon Travers, Arthur Ransome, Kenneth Grahame, M. Leaf, Marjorie Kinnan Rawlings, G. Owl, Adrienne Thomas, E.T. Seton, H. Washburne ${ }^{38}$, Eleanor Atkinson, Francis Finn,

\footnotetext{
34 She also used K. Elwira codename and aliases: El-Kor, Ewa Reńska, Płomyczek.

35 The list of translators who often translated literature for young readers included also: Marceli Tarnowski, H. Bokserówna, Franciszek Mirandola (pseud., wł. Franciszek Pik), Michalina Marczewska, Maria Arct-Golczewska (codename. M.A.G.), Zofia Dromlewiczowa, Jan Walicki (alias, coorect. Seweryn Albert Hartman), Jerzy Marlicz (alias, correct. Halina Borowikowa), Stefania Heymanowa, Janina Mortkowiczowa, Janina Zawisza Krasucka, Maria Feldmanowa (also under aliases: Maria Kreczowska, Eliza Warzycka), Maria Julia Zaleska and others.

36 Correctly: sir James Matthew Barrie.

37 Eleanor Hodgeman Porter.

38 Heluiz Chandler Washburne.
} 
W. Katajew, E. Kästner, and the others. The Polish reader of that time could have been a recipient of the most important and most widely read many works of European literature (as well as American and Canadian ones), which - mostly due to reissues - were given a chance to stay longer in his/her consciousness, and permanently entered the reading repertoire of that time.

\subsection{Translations in publication series}

The publishers willingly offered works for children in different series in the interwar period. It organized book production, attached potential readers to a permanent form of liked books, encouraged to gathering collections, and thus to the systematic purchase of the successively issued volumes. Translations were also placed in the series, in particular, literature for the youngest, fairy tales, adventure and travel literature. More than $40 \%$ of translations were published within a series. Those in which more than 20 titles of foreign authors were published are $^{39}$ :

- Księgozbiorek Dziecięcy (Children Book Collection, 123 titles) - Księgarnia Nakładowa, later Nowe Wydawnictwo,

- Zajmujące Czytanki (Interesting Readings, 56 titles) - M. Arct,

- Skarbnica Milusińskich (The Little Ones'Treasury, 54 titles) - Księgarnia Popularna,

- Biblioteka Książek Błękitnych (Blue Books Library, 38 titles) - Dom Książki Polskiej, E. Wende,

- Nowa Biblioteczka dla Dzieci i Młodzieży (New Library for Children and Young Adults, 35 titles) - Nowe Wydawnictwo, Księgarnia Ch.I. Roseweina,

- Czarodziejskie Baśnie (Magic Fairy Tales, 30 titles) - mostly Księgarnia Popularna,

- Biblioteczka dla Dzieci (Library for Children, 23 titles) - F. Korn,

- Zajmujące Czytanki Przyrodnicze (Exciting Nature Readings, 21 titles) - M. Arct.

The series consisted mostly of fairy tales, adventure and travel literature, and fantasy. Definitely, the most active publisher of foreign literature in series was Księgarnia Nakładowa (hereafter: Nowe Wydawnictwo), which published in the longest series of foreign language texts of that time (namely Księgozbiorek Dziecięcy) fairy tales in cheap, pocket editions. Works of the Polish authors interweaved with foreign titles, which naturally complemented and enriched the offer of the former in all these series. Interestingly, there was also the series specialized in specific types of literature, e.g. popular, "penny" series Zajmujące Czytanki

39 All the publishing houses mentioned below were active in Warsaw. 
published by M. Arct, offering Czech literature. The novels by R. Kipling for young adults were published in the series Biblioteka Laureatów Nobla Wydawnictwa Polskiego $^{40}$ (The Nobel Laureates Library of Wydawnictwo Polskie), a few of them several times: The Jungle Book (Księga dżungli), The Second Jungle Book (Druga księga dżungli), Captains Courageous (Kapitanowie zuchy. Powieść o wielkich tawicach morskich), Puck of Pook's Hill (Puk z Pukowej Górki), Kim, Stalky \& Co. (Stalky i Sp.). Foreign works of popular science literature were also assimilated in the series of this genre, in particular, nature and geographical ones. For example, as many as 5 (from among 12 published volumes in total ${ }^{41}$ ) scientific mini-books of foreign authors were published in the series Biblioteka Naukowa dla Młodzieży, published by Księgarnia Powszechna in Kraków ${ }^{42}$.

However, publishers of that time - in the market work system of their companies - expected profit from publishing in particular "popular" literature, i.e. the one really and highly demanded: books with the element of sensation, novels for girls, fiction, light, easy and relaxing literature. It became cyclical in particular when the young reader got attached to the series and collected it or was searching for favorite books in a library.

$* * *$

Bibliographical method, although not entirely perfect, and not allowing a description of the translation phenomenon in all its aspects, nevertheless allows stating the thesis of their abundance and diversity in the interwar book market, as well as refute some stereotypical statements concerning editions of that time ${ }^{43}$. It was the time when the domestic publishing market had been developed and stabilized in the reborn state. The offer of world literature for Polish children and young adults had been developed laboriously, but successfully. Selected titles, although not entirely highly evaluated, or even depreciated, in particular, those of adventure character, brought a breath of lightness and fascination with adventure to the publishing offer and perfectly adapted to the young readers' taste. Ambiguous tone of these novels was mostly criticized: descriptions of crazy

40 Hereafter: Wydawnictwo Polskie R. Wegner, Wydawnictwo Polskie R. Wegnera.

41 Bibliography of Krassowska and Grefkowicz in the list of series omits one of the volumes of this series, registration number 1928: J. Feldhorn, Wieści płyna w świat, Kraków 1938.

42 These were the books: O. Drogin, Myślace maszyny (translation from the Russian language, 1938); W.M. Reed, Ziemia. Historia gór, rzek, zwierząt i ludzi (translation from the English language, 1938); W.M. Reed, W.S. Bronson, Życie oceanu (translation from the English language, 1938); A.C. Tedesco Dalekie światy (przekład z włoskiego, 1937); H. Washbourne, Przez lądy i morza (translation from the English language, 1937).

43 E.g. one can read in Stownik literatury dziecięcej $i$ młodzieżowej... about a huge popularity of Jack London's books that time (p. 230), while only 6 titles of this author were published that time, each in one edition only. 
expeditions to the other side of the world "to get justice", Indian or Wild West stories. The biggest trouble makers were their heroes, who beat, smoke, tricked, avoided or openly violated the low, were familiar with revenge, drunkenness, inappropriate behaviors, jokes, stories, and weakness for the other $\operatorname{sex}^{44}$. Sensations and criminals were in question, Sherlock Holmes in particular. Criticized were also the sentimental novels for girls and romances: soppy, infantile, appealing to the lowest instincts, unnecessary and prematurely (in the reviewers' opinions) awakening interests in the topics inadequate for girls, and also corrupting, as suggesting that good marriage solves all life problems ${ }^{45}$. Obviously, there were also opinions defending such a literature, indicating its different functions for reading development of a young reader, advising consideration in formulating ineffective restrictions hindering access to books of lower educational or artistic value, because - according to these supporters - amateurs of fast action, sensation, thrill, suspense, description of hot feelings will always find a way to such books ${ }^{46}$. Moreover, as reasonably wrote J. Korczak, true reading interests had to be accepted and recognized, that it always could have been a way to more valuable works: "I know cases when a boy went from scandal brochures from a bin at a market place Kiercelak ${ }^{47}$, through Cooper, Verne, Sienkiewicz, Hugo - to Jan Krzysztof and Żeromski. However, I do not know any opposite case" ${ }^{48}$. These theses were difficult to accept in a time when so many postulates concerning useful, good, adequate book for children were formulated ${ }^{49}$ in the reborn homeland, when lists and catalogs of valuable books were developed by school authorities, organizations and associations, publishers and booksellers, church circles and private persons ${ }^{50}$. They included a lot of the best literature by foreign authors. Meanwhile,

${ }^{44}$ See also e.g. S. Bełżecki, B. Kierzkowska, K. Króliński. Articles concerning harmfulness of such a literaturę were published regularly by the journals: "Przegląd Pedagogiczny", "Praca Szkolna", "Miesięcznik Katechetyczny i Wychowawczy", "Młoda Matka", "Moja Przyjaciółka", "Opieka nad Dzieckiem”, “Życie Szkolne”.

45 E.g. K. Kuliczkowska, Z. Leśnodorski, A. Łasiewicka.

46 E.g. Helena Radlińska, J. Korczak.

47 Kercelak, "Kiercelak", the Kerceli Square - former square in the Wola district in Warsaw, and a market at this square active in the years 1867-1947. The cross of Okopowa and Solidarności streets is named "Kercelak" rondabout since 2001.

48 J. Korczak, Gazetka - kino - książka, "Świat Książki" 1929, no 4-5, p. 5.

49 Translations of literature for the youngest readers were often rejected, criticised for their wonder (e.g. One Thousand and One Nights) or cruelty (tales of brothers Grimm). Among others, Władysław Mieczysław Kozłowski thought so, and expressed that in his handbooks concerning adequate literature for children and young adults. Zdzisław Dębicki even claimed that this "part of literature should only be indigenous, homemade. Using foreign patterns is quite unacceptable and should be abandoned". Cited after Z. Dębicki, Książka i człowiek, $2^{\text {nd }}$ edition, Kraków 1923, p. 79.

50 See: I. Michalska, op. cit. i Anna Nosek (Zalecenia dotyczace czytania ksiażek beletrystycznych $w$ polskich poradnikach czytelniczych z międzywojnia, "Linguodidactica" 2012, no 16, pp. 157-167; Wzory $i$ antywzory postaw oraz zachowan czytelniczych młodego odbiorcy w świetle wybranych polskich poradników z okresu międzywojennego, [in:] Czytanie, czytelnictwo, czytelnik, 
the popularity of those lighter lectures, according to some critiques inappropriate, harmful, gutter, cheap, or even sometimes "forbidden" 51 , was proved by the readers' opinions described in the results of pre-war surveys conducted mostly by the educators of that time ${ }^{52}$. Anyway, thanks to the books of foreign authors Polish children and young adults were introduced to the circle of renowned world classics of literature in the interwar period, and they had a chance to know the most read, although popular works. These books still served after World War II (often preserved meticulously in home libraries, borrowed among families and friends, spared from purges in a few public libraries), when the works of foreign authors could not have been accepted for publishing. Language mosaic and variety of authors and subjects of these translations have not been restored for a long time after the war (mostly due to political reasons) $)^{53}$. Only the contemporary situation of the publishing market of translations for young readers seems to resemble that period. English literature dominates again, although the representation of other languages against the expansion of English culture is quite limited ${ }^{54}$.

Translated by Matgorzata Kisilowska

ed. by A. Żbikowska-Migoń, A. Łuszpak, Wrocław 2011, pp. 309-321).

${ }_{51}$ The term used by Jan Kuchta in the book Ksiażka zakazana jako przedmiot zainteresowań młodzieży w okresie dojrzewania, Warszawa 1934.

52 Results of surveys based on data from reading questionnaires, regarding genre, subject, and authors of favorite books, were published (among others) by: S. Baley, S. Drzewiecki, B. Grosglikowa, J. Joteyko, J. Kuchta, M. Potworowska-Dmochowska, A. Reiterowa, S. Świdwiński, J. Wuttkowa, A. Żebrowska.

53 I wrote about that in the articles: Przekłady z literatur obcych $w$ latach 1945-1989, [in:] Literatura dla dzieci i młodzieży (1945-1989). Vol. 3, ed. by K. Heska-Kwaśniewicz and K. Tałuć, Katowice 2013, pp. 149-165 and Przeklady literatury dla dzieci i młodzieży na polskim rynku wydawniczym oraz wydania polskich ksiażek za granica w latach 1990-2014, [in:] Literatura dla dzieci i młodzieży. Vol. 5, ed. by K. Tałuć, Katowice 2017, pp. 333-359. Percentage share of translations (titles) in the total publishing production for children and young adults after the war in Poland accounted between 13,8\% (1959) and 30\% (1956). However, this value did not exceed $20 \%$ in the 60s. Translations from the Russian language and languages of Eastern block countries prevailed. In the years 1986-1989 translations from works of foreign literature made again 24-30\% of total number of titles of literature for children and young adults, and this number was growing. In the 90s. the English literature prevailed - more than $51 \%$ in total of all translated editions came from English language countries, mostly from Great Britain. Translations share in production of books for children and young adults was significant in 2013 (56\% and 47\% respectively). In both groups the most of translations were from English, followed by French and German, Russian (translations for children only), then Italian, Spanish, and Swedish.

54 Translations made $62 \%$ of publishing production for young adults in 2016 , and this value was higher than a year before ( $2015-55 \%)$. These included mostly books translated from English (three quarters of all translations of literature for young adults), significantly less often from French (6\%), Spanish (5\%), German (4\%), Japan (4\%), and Swedish (3\%). As for literature for children, foreign books made $37 \%$, similarly to the year before. Books for children are most often translated from the English language (54\%), Italian (11\%), French (10\%), Swedish (4\%), and Spanish (3\%). Source: "Ruch Wydawniczy w Liczbach [2016 Książki] 2017, vol. 63, [online] http://ksiegarnia.bn.org.pl/ pdf/Ruch\%20wydawniczy\%20w\%20liczbach\%20tom\%2063.pdf [retrieved at 20.03.2018]. 


\section{References}

Andrzejewska J., Badania czytelnictwa w Polsce do 1939 r., "Studia o Książce" 1986, vol. 16, pp. 73-139.

Białek J.Z., Literatura dla dzieci i młodzieży w latach 1918-1939, Warszawa 1987.

Brzozowska S., Andersen w Polsce. Historia recepcji wydawniczej, Wrocław 1970.

Budrewicz Z., Ekodyskurs wychowawczy w międzywojennej literaturze dla dzieci i młodzieży, [in:] O etosie książki. Studia z dziejów bibliotek i kultury czytelniczej, ed. by T. Wilkoń, Katowice 2017, pp. 661-678.

Dębicki Z., Książka i człowiek, $2^{\text {nd }}$ edition, Kraków 1923.

Frycie S., Ziółkowska-Sobecka M., Bojda W., Leksykon literatury dla dzieci i młodzieży, Piotrków Trybunalski 2007.

Hadaczek B., Wychowanie przez literaturę w Polsce międzywojennej (związi literatury dla dzieci z pedagogika), Warszawa-Poznań 1973.

Kieniewicz T., Recepcja literatury amerykańskiej $w$ Polsce $w$ dwudziestoleciu międzywojennym, Warszawa 1977.

Korczak J., Gazetka - kino - książka, "Świat Książki” 1929, no 4-5, p. 5.

Krajewska A.M., Trzy legendy. Walka o niepodlegtość i granice w polskiej międzywojennej literaturze młodzieżowej, Warszawa 2009.

Krassowska B, Grefkowicz A., Bibliografia literatury dla dzieci i młodzieży 1918-1939: literatura polska i przekłady, Warszawa 1995.

Kraśko N., Instytucje wydawnicze w II Rzeczypospolitej, Warszawa 2001.

Michalska I., Wychowanie do czytelnictwa uczniów szkół powszechnych w Drugiej Rzeczypospolitej, Łódź 2011.

Kuchta J., Książka zakazana jako przedmiot zainteresowań młodzieży w okresie dojrzewania, Warszawa 1934.

Nikliborc A., Od baśni do prawdy. Szkice dziejów literatury zachodniej dla dzieci i mtodzieży, Warszawa 1981.

Nosek A., Wzory i antywzory postaw oraz zachowań czytelniczych młodego odbiorcy w świetle wybranych polskich poradników z okresu międzywojennego, [in:] Czytanie, czytelnictwo, czytelnik, ed. by A. Żbikowska-Migoń, A. Łuszpak, Wrocław 2011, pp. 309-321.

Nosek A., Zalecenia dotyczace czytania ksiązek beletrystycznych w polskich poradnikach czytelniczych z międzywojnia, "Linguodidactica" 2012, vol. 16, pp. 157-167.

Paprocka N., Rynkowe przygody Małego Księcia, czyli o przyczynach powstania dwunastu przektadów utworu Antoine'a de Saint-Exupéry'ego, "Filoteknos. Literatura dziecięca - Mediacja Kulturowa - Antropologia Dzieciństwa” 2010, no 1, pp. 146-158.

Paprocka N., Sto lat przekładów dla dzieci i młodzieży w Polsce. Francuska literatura dla młodych czytelników, jej polscy wydawcy i ich strategie (1918-2014), Kraków 2018.

Plis J., "Pod Znakiem Maryi”. Miesięcznik Związku Sodalicji Mariańskich Młodzieży Szkót Średnich w Polsce (1920-1939), [in:] O etosie książki. Studia z dziejów bibliotek i kultury czytelniczej, ed. by T. Wilkoń, Katowice 2017, pp. 757- 770. 
Słownik literatury dziecięcej i młodzieżowej, ed. by B. Tylicka, G. Leszczyński, Wrocław 2002.

Repucho E., Książka dla dzieci w stużbie estetyki druku. Publikacje dwudziestolecia międzywojennego, "Bibliotheca Nostra" 2016, no 1 (43), pp. 51-65.

"Ruch Wydawniczy w Liczbach [2016 Książki] 2017, vol. 63, [online] http://ksiegarnia. bn.org.pl/pdf/Ruch\%20wydawniczy\%20w\%20liczbach\%20tom\%2063.pdf [retrieved at 20.03.2018].

Stownik literatury polskiej XX wieku, ed. by A. Brudzka et al., Wrocław 1992.

Socha I., Czasopisma dla młodzieży - literatura piękna - wychowanie literackie (19181939), Katowice 1990.

Staniów B., Czytelnictwo książki popularnonaukowej dla dzieci i młodzieży w Polsce do 1989 roku (w świetle badań), "Bibliotheca Nostra. Śląski Kwartalnik Naukowy" 2016, no 1, pp. 105-126.

Staniów B., Grimm's Fairy Tales in Poland: the analysis of publishing production in the years 1895-2011, "Annales Universitatis Paedagogicae Cracoviensis. Studia ad Bibliothecarum Scientiam Pertinentia" 2014, [no] 12, pp. 5-18.

Staniów B., Książka amerykańska dla dzieci i młodzieży w Polsce w latach 1944-1989. Produkcja i recepcja, Wrocław 1996.

Staniów B., Przekłady literatury dla dzieci i młodzieży na polskim rynku wydawniczym oraz wydania polskich ksiązek za granica w latach 1990-2014, [in:] Literatura dla dzieci i młodzieży. Vol. 5, ed. by K. Tałuć, Katowice 2017, p. 333-359.

Staniów B., Przekłady z literatur obcych w latach 1945-1989, [in:] Literatura dla dzieci i młodzieży (1945-1989). T. 3, ed. by K. Heska-Kwaśniewicz and K. Tałuć, Katowice 2013, pp. 149-165.

Staniów B., Serie ksiażek popularnonaukowych dla dzieci i młodzieży w Polsce międzywojennej jako źródło informacji o świecie, nauce i człowieku (na wybranych przykładach), [in:] Przestrzeń informacyjna ksiązki, ed. by J. Konieczna, S. Kurek-Kokocińska, H. Tadeusiewicz, with cooperation of R. Kępa, M. Przybysz-Stawska, Łódź 2009, pp. 339-353.

Waksmund R., Od literatury dla dzieci do literatury dziecięcej (tematy, gatunki, konteksty), Wrocław 2000.

Woźniak M., Biernacka-Licznar K., Staniów B., Przekłady w systemie matych literatur: o włosko-polskich i polsko-włoskich tłumaczeniach dla dzieci i młodzieży, ed. by M. Woźniak, Toruń 2014. 